\title{
Three types of greenstone from the Hidaka belt, Hokkaido, Japan: Insights into geodynamic setting of northeastern margin of the Eurasian plate in the Paleogene
}

\author{
Toru YAMASAKI ${ }^{*}$ and Futoshi NANAYAMA ${ }^{* * * *}$ \\ *Institute of Geology and Geoinformation, Geological Survey of Japan (AIST), Tsukuba 305-8567, Japan \\ ${ }^{* *}$ Center for Water Cycle, Marine Environment and Disaster Management, Kumamoto University, Kumamoto 860-8555, Japan
}

\begin{abstract}
The Hidaka belt in Central Hokkaido, Japan, consists of an early Paleogene subduction complex, referred to as the Hidaka Supergroup, dominated by clastic rocks. The southern area of the Hidaka Supergroup is referred to as the Nakanogawa Group, which gradually leads to the high-temperature Hidaka metamorphic belt in the western part. We collected 17 samples of greenstone from the entire Hidaka belt and examined their wholerock major and trace element geochemistry. Including those described in previous reports, three distinct types of greenstone exist in the Hidaka belt. Type 1 greenstone is an ocean island basalt-type greenstone. The multielement and rare earth element (REE) patterns for this type of greenstone show a steep slope up to the left, with $\mathrm{Ti} / \mathrm{V}>62$ and $\mathrm{Zr} / \mathrm{Nb}<15$. Type 2 greenstone is a mid-ocean ridge basalt (MORB)-type greenstone that shows relatively flat chondrite-normalized REE patterns and a gentle slope up to the left on the normal-MORBnormalized multi-element patterns with $\mathrm{Ti} / \mathrm{V}=26-53$ and $\mathrm{Zr} / \mathrm{Nb}=21-117$. Type 3 greenstone shows multielement and REE patterns similar to those of Type 1, but with a clear relative depletion of $\mathrm{Nb}$, Ta, and Ti. In addition, its Ti-V relations are similar to those of Type 2 greenstone. Type 1 and Type 3 greenstones occur only in the Nakanogawa Group. Type 2 greenstone is mostly distributed in the northern the Hidaka Supergroup. Type 1 and Type 3 greenstones were generated by igneous activity on the Izanagi Plate, which was being subducted during the formation of the subduction complex of the Hidaka belt. Type 2 greenstone is interpreted as a product of a spreading axis that was active during the formation of the same subduction complex. Whereas Type 2 greenstone has been regarded as having a typical MORB-like geochemical signature, our results show slightly different, Indian Ocean MORB-type trace element patterns. These geochemical signatures are different than those of the amphibolites in the Hidaka metamorphic belt. The protolith of the amphibolite is not equivalent to the Type 2 greenstones and is probably an accreted fragment of an older oceanic plate. Type 2 greenstone was presumably generated from upper mantle with an Indian mantle-like geochemical signature during the Izanagi-Pacific ridge subduction on the western margins of the Pacific Ocean around $48 \mathrm{Ma}$.
\end{abstract}

Keywords: Hidaka belt, Hidaka Supergroup, Nakanogawa Group, Indian Ocean MORB, Whole-rock trace element

\section{INTRODUCTION}

Hokkaido, the northernmost major island of Japan, is located at the junction of two active island-arc-trench systems, the northeast Honshu Arc-Japan Trench along the eastern margin of the Eurasian continent and the Kuril Arc-Kamchatka Trench system that extends from Kamchatka Peninsula to eastern Hokkaido (Fig. 1a). Hokkai-

doi:10.2465/jmps. 190617

T. Yamasaki, t.yamasaki@aist.go.jp Corresponding author do is divided into three major geotectonic units (Western, Central, and Eastern Hokkaido; Fig. 1b) based on preEocene basement geology (e.g., Kiminami et al., 1986; Niida and Kito, 1986; Arita et al., 2003). Western Hokkaido is the northern extension of northeast Honshu, and it consists of Jurassic subduction complexes with Cretaceous extrusive and intrusive formations along the eastern margin of the Eurasian continent (e.g., Kawamura et al., 1986; Kiminami, 1986). Central Hokkaido consists of the Sorachi-Yezo belt in the west and the Hidaka belt in the east. The Sorachi-Yezo belt is composed of Cretaceous 
forearc-basin clastic sediments that overlie an ophiolite and siliceous sedimentary sequence of Late Jurassic to Early Cretaceous age, as well as the Cretaceous high- $P /$ $T$ Kamuikotan metamorphic rocks (Ueda, 2016). The Hidaka belt consists of an early Paleogene subduction complex that is dominated by clastic rocks (Ueda, 2016). Eastern Hokkaido is made up of a Late Cretaceous subduction complex associated with fragments of seamounts (partly metamorphosed to high- $P / T$ metamorphic rocks), which is referred to as the Nikoro Group in the Tokoro belt (Research Group of the Tokoro Belt, 1984; Sakakibara, 1986; Sakakibara et al., 1986; Toda and Niida, 1986) and Late Cretaceous to early Eocene forearc-basin sediments with arc volcanic rocks that are known respectively as the Saroma and Nemuro groups in the Tokoro and Nemuro belts (Kiminami and Kontani, 1983).

A high-temperature metamorphic belt, namely the Hidaka metamorphic belt (HMB), is distributed in the southwestern portion of the Hidaka belt (Fig. 1b). This metamorphic belt exhibits an eastward-tilted metamorphic sequence with felsic to mafic intrusive rocks that are considered to be a series of exposed crustal cross sections from west (deeper) to east (shallower), derived from an immature island arc (Komatsu et al., 1989; Osanai et al., 1991). The metamorphism of the HMB had been considered to be a thermal response to underplating of mafic magma into deeper portions of the accretionary prism (Hidaka belt) due to subduction of the Kula-Pacific ridge at $55 \mathrm{Ma}$ (e.g., Maeda and Kagami, 1996). In the 2000s, zircon $\mathrm{U}-\mathrm{Pb}$ ages from metamorphic and igneous rocks yielded two thermal pulses of 37 and $19 \mathrm{Ma}$ from the HMB (Usuki et al., 2006; Kemp et al., 2007), and Kemp et al. (2007) mentioned that peak metamorphism occurred at 19 Ma. Jahn et al. (2014) also reported three pulses of zircon $\mathrm{U}-\mathrm{Pb}$ ages, namely 46-45, 37, and 19-18 Ma, from plutonic rocks in the Hidaka belt. These new age data forced a reconsideration of the magmato-metamorphic model of the Hidaka belt and HMB.

In the Hidaka belt, greenstone was extruded upon or intruded into unconsolidated sediments in the northern area, and this formation has been interpreted as contemporaneous igneous activity and sedimentation in a trench area (i.e., in-situ basaltic magmatism during the sedimentation of trench-fill deposits) (Kiminami et al., 1986; Kiminami et al., 1999; Miyashita and Kiminami, 1999). This so-called 'in-situ greenstone' consists mainly of dolerite, massive lava, and pillow lava, and it is regarded as having the geochemical characteristics of the normal mid-ocean ridge basalts (N-MORBs) that formed at the subducting oceanic ridge near the Eurasian continent (Miyashita and Katsushima, 1986; Miyashita and Yoshida, 1994; Miyashita et al., 1997; Miyashita and Kiminami, 1999). Kawanami et al. (2006) reported that metabasites in the HMB and greenstones in the northern Hidaka belt, including in-situ greenstone, exhibit N-MORB-like whole-rock geochemical composition and $\mathrm{Sr}$ isotopic signatures.

The data described above, and observations and interpretations of the in-situ greenstone in previous studies, strongly constrain the igneous processes and geodynamic setting of the Hidaka belt, but examination of geochemical data for these greenstones has, in fact, been insufficient. Fundamental problems latent in previous work are as follows: 1) Previous discussions were based mainly on mineral chemistry and whole-rock major and minor element compositions. Whereas the metabasites from the HMB show typical N-MORB-type rare-earth element (REE) patterns (Mikoshiba-Ujiie, 1999; Kawanami et al., 2006; Yamasaki et al., 2018), virtually no report describes the multi-trace elements, including REEs from the in-situ greenstone, in the northern Hidaka belt. This information is critically important for specifying the origin of metabasites in the HMB. Although the Sr isotopic composition of greenstones and metabasites is an important clue for understanding the source material of these magma deposits, it does not fully constrain its geodynamic setting. In addition, such in-situ greenstone has been reported from the northern area of the Hidaka belt; however, there have been no reports yet from the southern area of the Hidaka belt. 2) Some of the in-situ greenstone in the northern Hidaka belt has experienced thermal metamorphism due to intrusion of granite (Miyashita et al., 1997), and the zircon $\mathrm{U}-\mathrm{Pb}$ age of the granite is $\sim 45$ Ma (Jahn et al., 2014). These lines of evidence suggest that the in-situ greenstone erupted before $45 \mathrm{Ma}$, and none of the three pulses of magmatic events might be involved in the ridge-subduction event. However, the relation between the oldest magmatic event $(\sim 45 \mathrm{Ma})$ and the timing of the ridge-subduction event is unclear at present. 3) Greenstones that do not have N-MORB-type compositions have been reported from the southern part of the Hidaka belt (Owada et al., 1992; Yamasaki and Nanayama, 2018). Some of these show a strongly alkaline whole-rock major and minor elemental geochemical nature (Owada et al., 1992), but multi-trace elements, including REEs, have not been reported. In addition, these types of greenstones have not been confirmed in the northern Hidaka belt and HMB.

The lack of detailed information on whole-rock trace element geochemistry and insufficient characterization of geochemical features prevents precise comparison of greenstones in the entire Hidaka belt, and this results in a patchy understanding of the geochemical nature and origin of greenstones region by region. Thus, it is important to revisit greenstone composition, especially in terms 


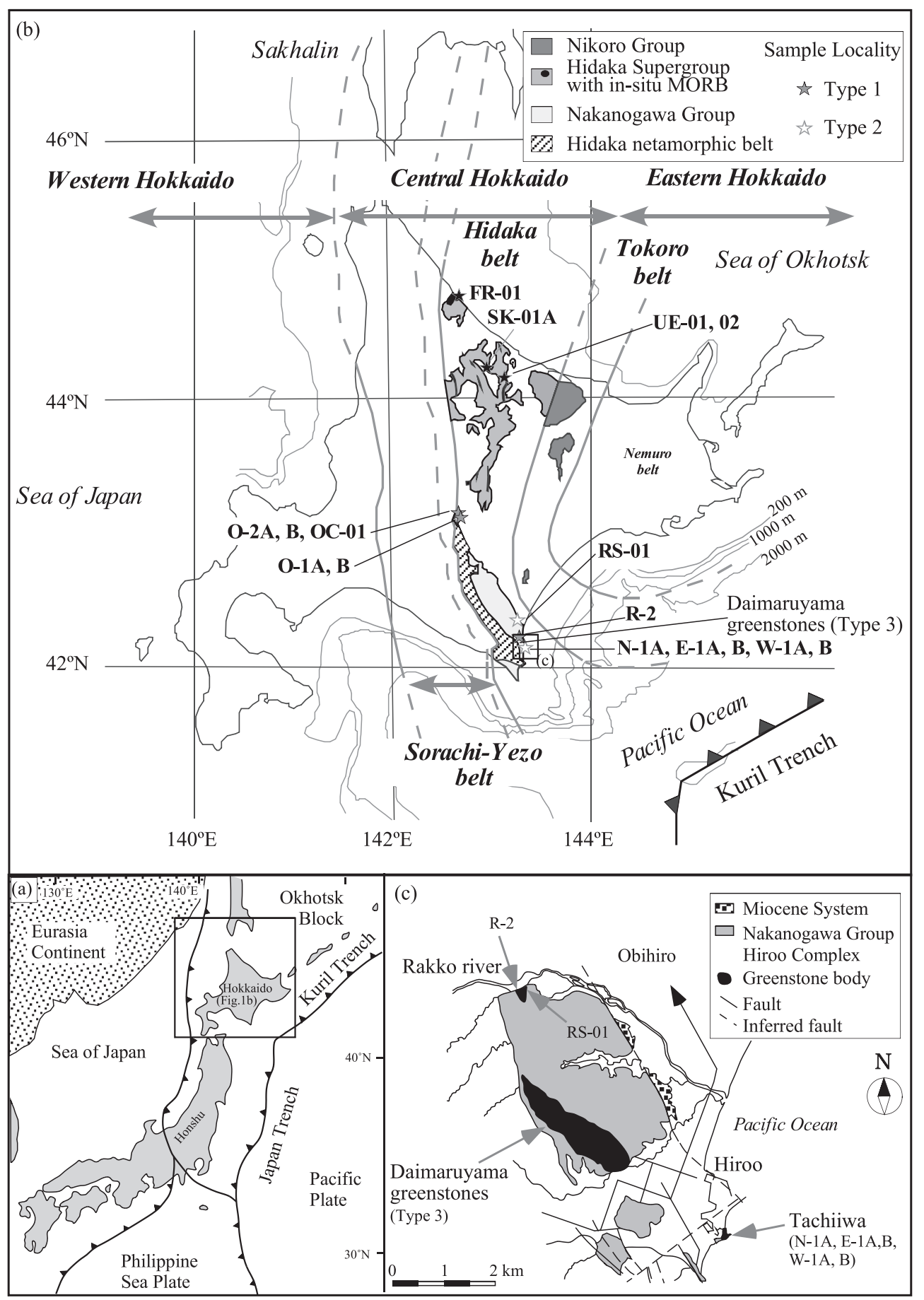

Figure 1. (a) Simplified tectonic map of the area around Japan and eastern Eurasia. (b) Tectonic map of central Hokkaido with sample locations (after Nanayama et al., 2018). (c) Simplified geologic map of the Hiroo area (modified from Yamasaki and Nanayama, 2018).

of multi-trace elements, including REEs, from the whole Hidaka belt, to reconfirm the geochemical features of the greenstones. To understand and re-evaluate the geochemical features of greenstone in the Hidaka belt, we collected 17 samples from the entire region of the belt and conducted whole-rock major and trace element analyses. Our final target was to reconstruct a coherent geodynamic model explaining the volcanic rock (now greenstone) formation using newly obtained data and existing literature data together. All samples described in this study are greenstones, whose original compositions (e.g., basalt, andesite, or dacite) were unclear in the field. Therefore, we also use the term greenstone for such rocks in the following descriptions. 


\section{GEOLOGICAL OUTLINE OF THE HIDAKA BELT AND DESCRIPTION OF SAMPLES COLLECTED}

The Hidaka belt contains a lower Paleogene subduction complex that comprises primarily Early Paleogene turbiditic sediments, with minor pelagic and mélange sediments, collectively referred to as the Hidaka Supergroup (Nanayama et al., 1993; Ueda, 2016; Nanayama et al., 2018). The Hidaka Supergroup, which is distributed along the Hidaka Mountains in southern Central Hokkaido, has been referred to as the Nakanogawa Group (Hasegawa et al., 1961). In this paper, use of the name Hidaka Supergroup is restricted to the northern half of the Hidaka belt (Fig. 1b). In the Hidaka Supergroup, existence of in-situ greenstone with $\mathrm{N}-\mathrm{MORB}$ compositions that extruded upon or intruded into unconsolidated sediments have been reported (Kiminami et al., 1986; Kiminami et al., 1999; Miyashita and Kiminami, 1999). These N-MORB effusive rocks in the Hidaka Supergroup are regarded as a protolith of the metabasites in the HMB (e.g., Komatsu, 1985; Osanai et al., 1989; Kawanami et al., 2006).

Nanayama (1992a) noted that the rocks along the eastern margin of the Nakanogawa Group were highly deformed compared with other parts of the Nakanogawa Group. These deformed rocks, named the Hiroo Complex (sedimentary complex), contain several allochthonous blocks of greenstone within a mélange (Nanayama, 1992a). The Tachiiwa body (Fig. 1c), one of these greenstone blocks, consists of alkaline volcanic rocks (Owada et al., 1992). Owada et al. (1992) reported whole-rock major and minor element compositions and mineral compositions of those volcanic rocks, but not trace-element compositions. The Daimaruyama mass (Fig. 1c) is the largest greenstone block in the Hidaka belt (e.g., Kontani et al., 1986; Nanayama, 1992a). Yamasaki and Nanayama (2018) presented an integrated set of major and trace element geochemical data for whole rocks and clinopyroxenes in the Daimaruyama greenstone body and concluded that the Daimaruyama greenstone was formed as a result of the subduction of the Izanagi Plate within the eastern realm of the proto-Pacific Ocean by the differentiation of basaltic magma, which presumably had enriched MORB (E-MORB)-like compositions under low-pressure hydrous conditions after the Early Cretaceous (Aptian-Albian, 125-101 Ma).

We collected 17 samples from the whole Hidaka belt region, including the in-situ MORBs from the northern Hidaka Supergroup (samples FR-01, SK-01A, UE-01, UE-02, O-1A, O-1B, O-2A, O-2B, and OC-01), small greenstone bodies (RS-01 and R-2), and Tachiiwa body (N-1A, E-1A, E-1B, W-1A, and W-1B) in the Hiroo Complex, southern Nakanogawa Group (Figs. 1b and 1c). Samples SK-01A, UE-01, UE-02, and FR-01 from the Hidaka Supergroup occurred as intrusions or lava that are the constituents of in-situ greenstone (Fig. 2a). Samples $\mathrm{O}-1 \mathrm{~A}$ and $\mathrm{O}-1 \mathrm{~B}$ were taken from a large intrusive body (Fig. 2b), and O-2A, O-2B, and OC-01 were taken from dikes (Fig. 2c) in the Hidaka Supergroup. Samples RS-01 and R-2 occurred as blocks with red chert in the sheared sedimentary rocks in the Nakanogawa Group (Fig. 2d). Samples N-1A, E-1A, E-1B, W-1A, and W1B were from a large Tachiiwa block that consists of greenstone (dike and tuff), micritic limestone, reddish bedded chert, and reddish mudstone in the Nakanogawa Group (Owada et al., 1992).

Basaltic greenstone from the Hidaka Supergroup shows an aphyric to porphyritic intersertal-variolitic texture (Fig. 3a). Phenocrysts or microphenocrysts of euhedral-subhedral plagioclase and clinopyroxene (1.5-0.5 $\mathrm{mm}$ along the long axis) are commonly observed. Completely altered pseudomorphs of euhedral-subhedral olivine phenocrysts $(0.5-0.2 \mathrm{~mm})$ are observed in some cases. Doleritic greenstone from the Hidaka Supergroup is characterized by an ophitic texture and consists mainly of euhedral-subhedral plagioclase $(1.0-0.5 \mathrm{~mm}$ in size) with interstitial oikocrystic clinopyroxene (Fig. 3b). In general, epidote, chlorite, actinolite, and other fine-grained clay minerals are present as secondary minerals. A detailed description of the mode of occurrence and petrography is given in Miyashita and Katsushima (1986), Miyashita and Yoshida (1994), and Miyashita and Kiminami (1999).

Greenstone sample R-2 from the Nakanogawa Group shows a porphyritic texture (Fig. 3c). Phenocrysts of euhedral plagioclase (0.8-0.2 mm along the long axis) are observed. The groundmass consists of fine-grained chlorite and other clay minerals. The groundmass shows original hyalopilitic or intersertal texture, while some portions are brecciated by deformation and/or show hyaloclastitic texture (Fig. 3c). Calcite veins are observed.

Sample RS-01 and greenstone from the Tachiiwa block shows porphyritic intersertal texture with euhedral-subhedral plagioclase phenocrysts (Fig. 3d). Existence of $\mathrm{K}$-feldspar phenocrysts has also been reported by Owada et al. (1992). The groundmass is dark brown under plane-polarized light and made up of very finegrained clay minerals. Secondary calcite veins are also observed in many cases. In some samples, subhedral brown amphiboles (kaersutite and salite) are also present. Detailed descriptions of the mode of occurrence and petrography are given in Owada et al. (1992).

\section{ANALYTICAL PROCEDURES AND RESULTS}

Powdered rock samples were prepared for X-ray fluores- 

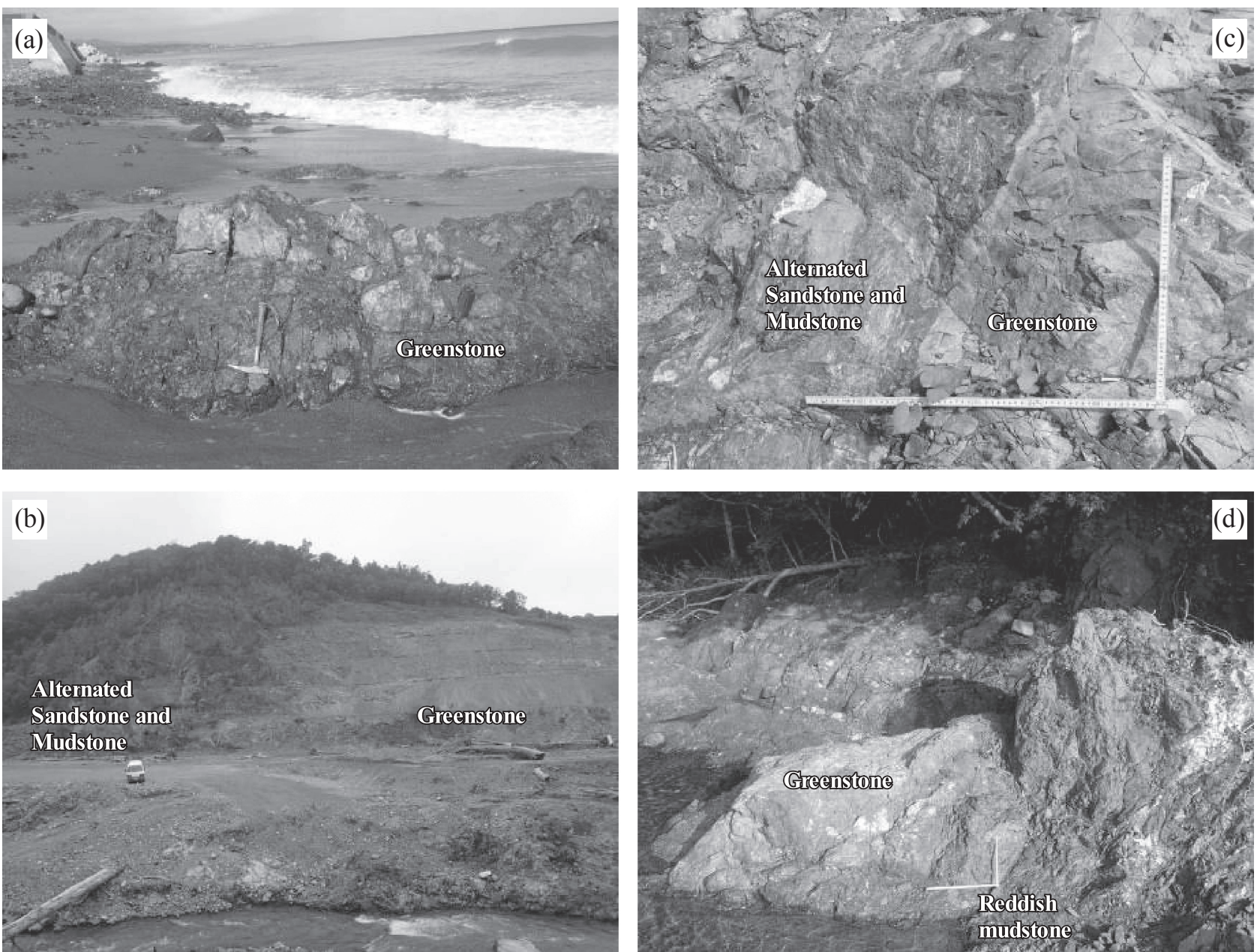

Figure 2. Field occurrence of greenstone in the Hidaka belt. (a) Outcrop for FR-01 in Esashi Town, which is located within the Hidaka Supergroup. In this area, various sizes of dikes and pillows intruded into or extruded upon black mudstone. (b) Large greenstone body for O-1A and O-1B at the quarry in Minami-Furano Town, located within the Hidaka Supergroup. (c) Greenstone dike for O-2a at MinamiFurano Town. Host rock is black mudstone in the Hidaka Supergroup. (d) Greenstone block for R-02 along the Rakko River in Hiroo Town, located within the Nakanogawa Group, southern Hidaka belt. The greenstone block occurs within deformed alternating sandstone-mudstone.

cence (XRF) spectrometry and whole-rock laser ablation-inductively coupled plasma-mass spectrometry (LA-ICP-MS) analyses. The surfaces of chips from samples were scraped with a diamond disk to remove contamination from the rock-cutting saw. After an initial cleanup of the surfaces, the chips were cleaned thoroughly with deionized water in an ultrasonic bath for more than $30 \mathrm{~min}$. The samples were then dried in an oven for more than $24 \mathrm{~h}$. The dried samples were coarsely crushed in a tungsten carbide mortar and then ground in a tungsten carbide mill.

Whole-rock major element compositions were measured with an XRF spectrometer (PANalytical Axios) at the GSJ-Lab of the Geological Survey of Japan (GSJ) using the method reported by Yamasaki (2014). Wholerock trace element compositions were measured using
LA-ICP-MS (New Wave Research NWR213 LA coupled with Agilent 7700x ICP-MS). Detailed analytical procedures are given in Yamasaki et al. (2015) and Yamasaki and Yamashita (2016). The data quality of the XRF and whole-rock LA-ICP-MS was monitored with measurements of U.S. Geological Survey and GSJ geochemical reference materials, respectively. Analytical results of the reference materials for whole-rock LA-ICP-MS analyses and studied samples are listed in Table 1.

\section{DISCUSSION}

\section{Geochemical subdivision of greenstone in the Hidaka belt}

All studied samples were altered in various ways and 

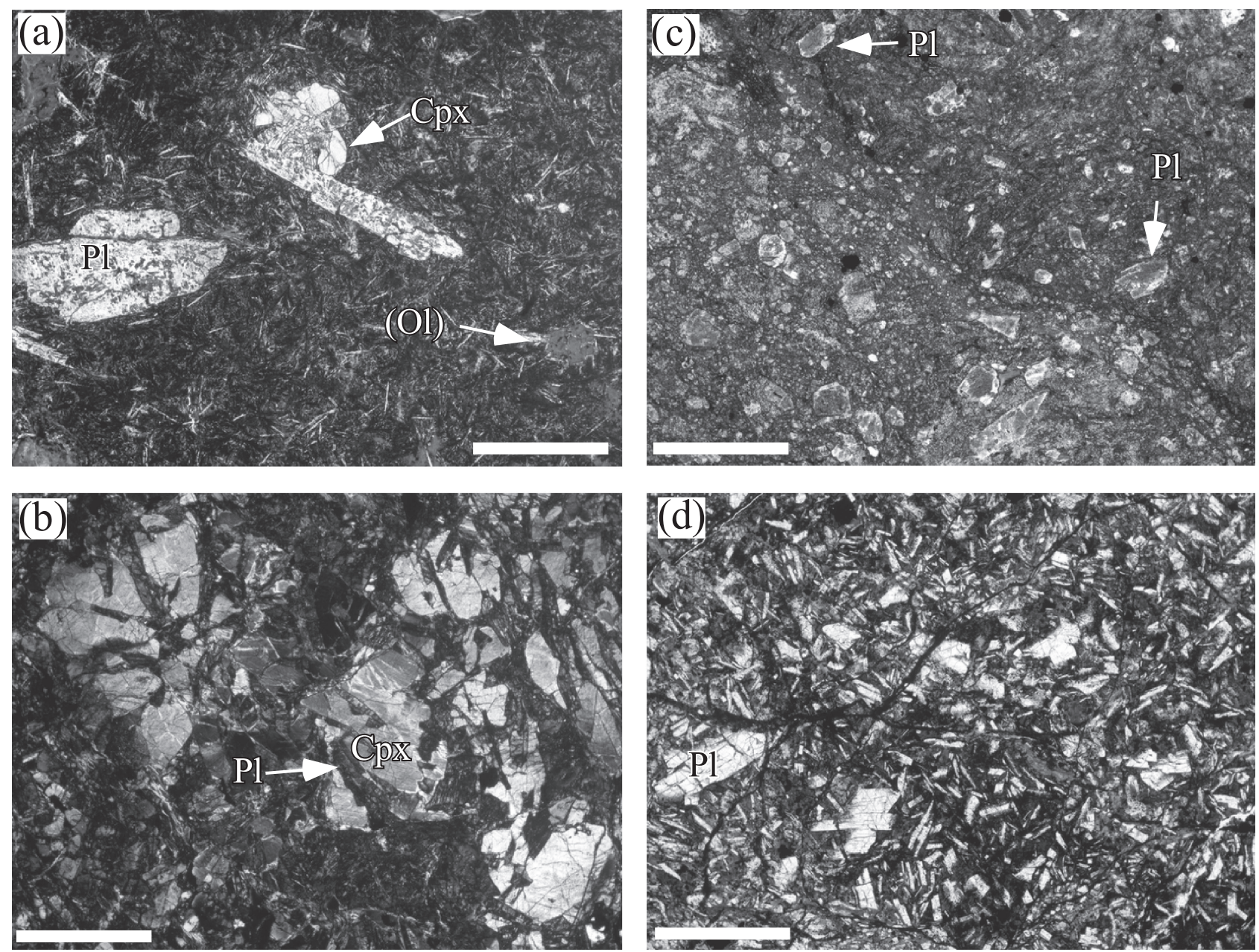

Figure 3. Thin-section micrographs of representative samples. (a) Basaltic greenstone from the Hidaka Supergroup (UE-02). (b) Doleritic greenstone from the Hidaka Supergroup $(\mathrm{O}-1 \mathrm{c})$. (c) Greenstone from the Nakanogawa Group (R-02). (d) Greenstone from the Tachiiwa block (N-1a). (a), (c), and (d) Plane-polarized light. (b) Cross-polarized light. Scale bars for all panels =1.0 mm. Cpx, clinopyroxene; Pl, plagioclase; $(\mathrm{Ol})$, olivine (pseudomorph). The upper right (dark) portion of panel (c) shows weak alignment of plagioclase phenocrysts and original hyalopilitic or intersertal texture. See text for description.

may not have preserved their original magmatic compositions. We assumed that all the samples suffered comparable alterations because there were no indications to the contrary. According to previous studies, original geochemical characteristics of whole-rock compositions are not completely modified in such greenstones, except for highly mobile, large-ion lithophile elements (e.g., Yamasaki and Nanayama, 2018). Thus, the proportions of Ti and $\mathrm{Zr}$, which are highly immobile, high-field-strength elements, were first examined. As a result, the studied greenstone from the Hidaka belt was subdivided into two major groups (Fig. 4). The first group (Type 1 greenstone) shows $\mathrm{Ti} / \mathrm{V}>50$, and it is plotted on the ocean island and alkalic basalts (OIA) field of the Ti/V diagram (Fig. 4). The second group (Type 2 greenstone) shows a $\mathrm{Ti} / \mathrm{V}$ ratio close to or less than 50 , and it is plotted on the MORB field of the Ti-V diagram (Fig. 4). Literature data for compositions of mafic volcanic rocks and metabasites from the Hidaka belt and Nikoro Group, Tokoro belt, are also plotted in Figure 4 for comparison. Type 1 greenstone is distributed in the Tachiiwa body and Rakko River area (RS-01) as blocks in the Hiroo Complex, Nakanogawa Group, in the southern Hidaka belt. The obtained data for the Type 1 rocks are comparable to those reported previously for the Tachiiwa body (Owada et al., 1992) and greenstones from the Nikoro Group (Sakai et al., 2019) (Fig. 4). The data for Type 2 greenstone in this study and all literature data of mafic volcanic-metavolcanic rocks, except for the Tachiiwa body and Nikoro Group, are plotted in the MORB field on the Ti-V diagram (Fig. 4).

Chondrite-normalized whole-rock REE patterns and N-MORB-normalized multi-trace element patterns (chondrite and N-MORB values after Sun and McDo- 
nough, 1989) for studied samples and literature data from the Hidaka belt and Nikoro Group, Tokoro belt, are shown in Figure 5. Representative compositions for N-MORB, E-MORB, and ocean island basalt (OIB) (Sun and McDonough, 1989) are also shown in Figure 5 for comparison. In terms of geochemical features of whole-rock REE patterns, the studied samples are also divided into two groups. The first group shows a steep slope up to the left from $\mathrm{Lu}$ ( $\sim 10$ times that of chondrite abundance) to $\mathrm{La}$ (200-300 times that of chondrites) (Fig. 5a). The second group shows nearly flat REE patterns, with 10-30 times the REE content of chondrites (Fig. 5b). The former group consists of Type 1 greenstone and the latter group consists of Type 2 greenstone. Trace element patterns of Type 1 greenstone resemble OIB and greenstones from the Nikoro Group reported by Sakai et al. (2019). The REE and multi-element patterns of Type 2 greenstone resemble E-MORB rather than N-MORB, while Type 2 includes the in-situ greenstone (in-situ N-MORB) in the Hidaka Supergroup. Because the metabasite (amphibolite) in the HMB shows typical N-MORB trace element compositions (e.g., Mikoshiba-Ujiie, 1999; Kawanami et al., 2006), Type 2 greenstone also differs chemically from those amphibolites in terms of trace element composition.

Including the geochemical data from our previous report (Yamasaki and Nanayama, 2018), a third type (Type 3) of greenstone, namely Daimaruyama greenstone, which is different than Types 1 and 2, exists in the Nakanogawa Group, southern Hidaka belt (Fig. 1). Type 3 greenstone is characterized by an OIB-like REE pattern with MORB-like $\mathrm{Ti} / \mathrm{V}$ ratio $(\mathrm{Ti} / \mathrm{V}=30-50)$ and negative anomalies of $\mathrm{Nb}, \mathrm{Ta}$, and $\mathrm{Ti}$ in the N-MORBnormalized multi-trace element patterns (Figs. 4 and 5; Yamasaki and Nanayama, 2018).

In summary, the greenstones in the Hidaka belt can be defined as three petrological-geochemical types. Type 1 greenstone consists of alkaline basalt to andesite (Fig. 6). This type of greenstone occurs as an allochthonous blocks in the Hiroo Complex, Nakanogawa Group, in the southern Hidaka belt. Type 2 greenstone is composed mainly of basalt-andesite with minor amounts of dacite that has E-MORB-like geochemical features (Figs. 5 and 6). This type of greenstone is distributed mainly in the Hidaka Supergroup (from the Esashi area of the northernmost Hidaka belt to the Ochiai-Shimokawa area), which is located adjacent to the northern end of the HMB in the southern central part of the Hidaka belt (Fig. 1). In addition to these locations, the occurrence of Type 2 greenstone was also confirmed at the Rakko River area in the Nakanogawa Group, southern Hidaka belt. Type 2 greenstone corresponds to the N-MORB in-situ greenstone that was reported by Miyashita and Katsushima (1986),
Miyashita and Yoshida (1994), and Miyashita and Kiminami (1999). It is noted that minor elements $(\mathrm{Nb}, \mathrm{P}, \mathrm{Zr}$, $\mathrm{Ti}$, and $\mathrm{Y}$ ) that were an important basis for identifying $\mathrm{N}$ MORB-like geochemical features in previous studies (e.g., Miyashita and Kiminami, 1999; Kawanami et al., 2006) cannot distinguish between E-MORB and NMORB (Fig. 5d). Thus, our data are essentially consistent with the data previously reported in terms of minor element composition. Type 3 greenstone shows a dacitic composition (Fig. 6) and MORB-like Ti/V ratio (Fig. 4). This type of greenstone shows gentle slopes up to the left on the N-MORB-normalized multi-trace element patterns, with negative $\mathrm{Nb}, \mathrm{Ta}$, and $\mathrm{Ti}$ anomalies (Fig. 5). The occurrence of this type of greenstone is limited to the Daimaruyama area in the Hiroo Complex in the Nakanogawa Group, southern Hidaka belt (Fig 1b; Yamasaki and Nanayama, 2018). A detailed description of the mode of occurrence and petrography of samples is given in Yamasaki and Nanayama (2018).

\section{Implications for geodynamic setting of the Hidaka belt}

The subduction complex of the Tokoro and Hidaka belts is essentially a contemporaneous heterotopic facies of the late Cretaceous (e.g., Ueda, 2016, and references therein). Type 1 greenstone has been presumed to be an intrusive body into ocean-floor sediments during the middle Cretaceous and to be consequently accreted to the Nakanogawa Group, which originated as an allochthonous block from the Nikoro Group in the Tokoro belt, based on the following major grounds for this interpretation (Owada et al., 1992; Nanayama, 1992a): (1) Type 1 greenstone has a highly alkaline whole-rock major element composition, and its minor element compositions are also alkaline in nature, (2) greenstone intruded into pelagic sediments, and now both the greenstone and host sedimentary rocks are included as a block within the Hiroo Complex, Nakanogawa Group, and (3) the K-Ar dating for the greenstone indicates an age of $95 \mathrm{Ma}$. Regarding these interpretations, the highly alkaline nature of the whole-rock composition has been an important basis for the origin of intra-oceanic basalt; however, in fact some of the alkaline element content in the whole-rock geochemistry has been unclear due to later alteration. In this study, the typical OIB-type whole-rock trace element composition of Type 1 has been confirmed, and Type 1 greenstone and greenstones in the Nikoro Group of the Tokoro belt seem to have a common origin (Figs. 4-6). In addition to this type of greenstone, Yamasaki and Nanayama (2018) suggested that the Type 3 Daimaruyama greenstone was probably submarine volcanic rock that formed as a result of the 
Table 1. Whole-rock major element (wt\%) and trace element $(\mathrm{ppm})$ compositions of greenstone samples

\begin{tabular}{|c|c|c|c|c|c|c|c|c|c|c|c|c|c|}
\hline \multirow[b]{2}{*}{ Sample } & \multicolumn{6}{|c|}{ Type 1} & \multicolumn{7}{|c|}{ Type 2} \\
\hline & $\mathrm{N}-1 \mathrm{~A}$ & E-1A & E-1B & W-1A & W-1B & RS-01 & $\mathrm{R}-2$ & $\mathrm{O}-1 \mathrm{~A}$ & $0-1 B$ & $0-1 \mathrm{C}$ & $\mathrm{O}-2 \mathrm{~A}$ & $\mathrm{O}-2 \mathrm{~B}$ & SK-01A \\
\hline $\mathrm{SiO}_{2}$ & 54.33 & 46.39 & 54.34 & 58.38 & 52.54 & 45.50 & 68.97 & 50.32 & 49.13 & 50.57 & 55.79 & 50.05 & 49.57 \\
\hline $\mathrm{TiO}_{2}$ & 2.45 & 3.43 & 2.02 & 2.27 & 1.76 & 3.46 & 0.57 & 1.10 & 0.95 & 1.53 & 1.07 & 1.01 & 1.88 \\
\hline $\mathrm{Al}_{2} \mathrm{O}_{3}$ & 14.36 & 14.95 & 16.24 & 12.15 & 15.77 & 17.30 & 13.41 & 17.68 & 19.42 & 16.36 & 19.45 & 18.29 & 14.81 \\
\hline $\mathrm{Fe}_{2} \mathrm{O}_{3}{ }^{*}$ & 13.55 & 10.15 & 8.24 & 9.93 & 8.22 & 11.62 & 5.69 & 9.41 & 8.04 & 10.10 & 6.77 & 6.77 & 11.32 \\
\hline $\mathrm{MnO}$ & 0.48 & 0.16 & 0.10 & 0.26 & 0.20 & 0.15 & 0.10 & 0.15 & 0.13 & 0.15 & 0.11 & 0.15 & 0.23 \\
\hline $\mathrm{MgO}$ & 3.36 & 3.35 & 2.74 & 3.52 & 2.38 & 3.60 & 1.91 & 5.95 & 6.85 & 7.68 & 6.16 & 7.73 & 5.94 \\
\hline $\mathrm{CaO}$ & 6.83 & 12.12 & 4.26 & 7.23 & 8.36 & 12.30 & 3.05 & 12.13 & 13.08 & 10.07 & 2.33 & 11.23 & 11.69 \\
\hline $\mathrm{Na}_{2} \mathrm{O}$ & 3.63 & 4.90 & 3.99 & 2.94 & 5.29 & 3.80 & 5.76 & 3.37 & 2.39 & 3.18 & 7.34 & 4.43 & 4.97 \\
\hline $\mathrm{K}_{2} \mathrm{O}$ & 0.48 & 3.87 & 6.59 & 2.94 & 4.09 & 1.65 & 0.07 & 0.21 & 0.12 & 0.53 & 0.20 & 0.16 & 0.12 \\
\hline $\mathrm{P}_{2} \mathrm{O}_{5}$ & 0.50 & 0.63 & 0.95 & 0.54 & 0.96 & 0.34 & 0.10 & 0.09 & 0.08 & 0.16 & 0.21 & 0.13 & 0.18 \\
\hline Total & 99.97 & 99.95 & 99.47 & 100.16 & 99.59 & 99.71 & 99.64 & 100.40 & 100.19 & 100.33 & 99.40 & 99.93 & 100.71 \\
\hline LOI & 3.20 & 9.21 & 2.74 & 4.99 & 5.57 & 8.85 & 2.96 & 1.81 & 2.11 & 2.98 & 3.54 & 5.17 & 5.15 \\
\hline $\mathrm{Ti}$ & 14017 & 20468 & 12639 & 13830 & 10522 & 19286 & 3208 & 5963 & 5205 & 7154 & 5547 & 5620 & 10831 \\
\hline V & 197 & 199 & 99 & 219 & 55 & 312 & 63 & 218 & 179 & 221 & 145 & 163 & 325 \\
\hline $\mathrm{Cr}$ & 34.5 & 87.9 & 14.4 & 123.6 & 30.1 & 134.5 & 37.0 & 303.0 & 279.9 & 229.9 & 258.5 & 267.5 & 258.9 \\
\hline $\mathrm{Ni}$ & 25 & 29 & 17 & 55 & 13 & $<0.000$ & 44 & 678 & 5 & 165 & 5 & 35 & 81 \\
\hline $\mathrm{Zn}$ & 158.8 & 111.0 & 135.8 & 127.0 & 76.0 & 167.8 & 60.6 & 90.3 & 54.1 & 104.9 & 115.7 & 52.3 & 92.9 \\
\hline $\mathrm{Rb}$ & 6.01 & 36.17 & 77.51 & 55.76 & 39.81 & 39.44 & 5.16 & 11.63 & 2.51 & 26.08 & 4.91 & 3.33 & 26.20 \\
\hline $\mathrm{Sr}$ & 306 & 345 & 310 & 282 & 445 & 346 & 133 & 166 & 166 & 145 & 202 & 293 & 176 \\
\hline $\mathrm{Y}$ & 40.7 & 26.3 & 32.4 & 33.8 & 29.0 & 25.2 & 27.0 & 19.5 & 17.9 & 21.7 & 20.2 & 15.0 & 36.2 \\
\hline $\mathrm{Zr}$ & 316.5 & 245.3 & 377.1 & 239.9 & 270.2 & 159.5 & 165.6 & 63.7 & 55.1 & 89.0 & 82.4 & 85.8 & 121.9 \\
\hline $\mathrm{Nb}$ & 35.07 & 45.18 & 57.44 & 32.93 & 42.14 & 11.17 & 5.32 & 1.33 & 1.28 & 3.43 & 3.41 & 3.32 & 2.76 \\
\hline $\mathrm{Ba}$ & 338 & 1578 & 2176 & 917 & 1910 & 740 & 109 & 16 & 15 & 60 & 106 & 81 & 81 \\
\hline $\mathrm{La}$ & 37.30 & 54.51 & 79.93 & 54.58 & 68.53 & 17.24 & 11.45 & 3.22 & 3.06 & 5.83 & 9.18 & 6.59 & 6.93 \\
\hline $\mathrm{Ce}$ & 79.3 & 112.0 & 170.5 & 100.9 & 138.8 & 40.2 & 27.5 & 5.9 & 6.9 & 14.0 & 21.5 & 13.1 & 12.7 \\
\hline $\operatorname{Pr}$ & 8.94 & 12.94 & 18.76 & 12.94 & 14.87 & 6.56 & 3.05 & 0.95 & 0.81 & 1.76 & 2.43 & 1.37 & 1.91 \\
\hline $\mathrm{Nd}$ & 39.6 & 48.2 & 67.0 & 40.4 & 55.6 & 16.7 & 17.7 & 7.4 & 4.7 & 10.7 & 15.3 & 10.1 & 9.1 \\
\hline $\mathrm{Sm}$ & 6.20 & 8.99 & 13.60 & 8.78 & 7.34 & 4.61 & 5.22 & 2.06 & 2.41 & 3.06 & 2.43 & 2.99 & 5.91 \\
\hline $\mathrm{Eu}$ & 2.9 & 2.9 & 3.7 & 2.5 & 3.8 & 2.0 & 1.9 & 1.2 & 0.7 & 1.0 & 1.3 & 1.4 & 1.9 \\
\hline $\mathrm{Gd}$ & 8.82 & 8.85 & 10.47 & 10.66 & 9.78 & 7.31 & 4.87 & 4.33 & 2.59 & 3.76 & 4.11 & 2.68 & 7.76 \\
\hline $\mathrm{Tb}$ & 1.22 & 0.90 & 1.49 & 1.17 & 1.26 & 1.06 & 1.23 & 1.01 & 0.74 & 0.74 & 0.92 & 0.75 & 0.91 \\
\hline Dy & 10.65 & 7.21 & 9.00 & 6.68 & 6.89 & 6.48 & 4.52 & 3.17 & 2.51 & 3.46 & 3.84 & 2.24 & 6.31 \\
\hline Ho & 1.82 & 1.12 & 1.1 & 1.05 & 1.19 & 1.25 & 1.16 & 0.97 & 0.60 & 0.77 & 0.99 & 0.69 & 1.12 \\
\hline $\mathrm{Er}$ & 4.09 & 2.09 & 2.8 & 3.20 & 2.47 & 2.71 & 3.49 & 2.58 & 2.21 & 3.05 & 2.03 & 1.70 & 5.13 \\
\hline $\mathrm{Tm}$ & 0.64 & 0.28 & 0.64 & 0.30 & 0.29 & 0.40 & 0.43 & 0.31 & 0.23 & 0.30 & 0.22 & 0.17 & 0.62 \\
\hline $\mathrm{Yb}$ & 3.48 & 1.42 & 1.82 & 1.40 & 1.99 & 1.55 & 2.96 & 2.02 & 1.94 & 2.22 & 1.16 & 1.78 & 4.83 \\
\hline $\mathrm{Lu}$ & 0.73 & 0.29 & 0.33 & 0.36 & 0.25 & 0.18 & 0.64 & 0.50 & 0.52 & 0.34 & 0.24 & 0.36 & 0.69 \\
\hline Hf & 9.69 & 5.44 & 8.16 & 6.29 & 6.48 & 3.71 & 5.35 & 2.22 & 1.87 & 2.51 & 2.29 & 2.76 & 3.19 \\
\hline $\mathrm{Ta}$ & 5.59 & 6.79 & 8.42 & 5.35 & 6.40 & 1.88 & 0.95 & 0.12 & 0.10 & 0.49 & 0.60 & 0.57 & 0.53 \\
\hline $\mathrm{Pb}$ & 2.87 & 2.96 & 5.18 & 7.20 & 4.86 & 0.95 & 1.05 & 5.01 & 0.39 & 1.06 & 1.13 & 0.97 & 0.29 \\
\hline Th & 4.13 & 3.87 & 6.47 & 3.34 & 4.28 & 0.71 & 0.94 & 0.09 & 0.08 & 0.40 & 0.67 & 0.42 & 0.28 \\
\hline $\mathrm{U}$ & 0.84 & 2.76 & 3.14 & 1.10 & 1.38 & 0.33 & 0.17 & 0.08 & 0.02 & 0.05 & 0.18 & 0.10 & 0.20 \\
\hline
\end{tabular}

Samples are from the Hidaka belt and comparison with reference materials.

$\mathrm{Fe}_{2} \mathrm{O}_{3}{ }^{*}$ denotes total $\mathrm{Fe}$ as $\mathrm{Fe}_{2} \mathrm{O}_{3}$ and LOI denotes loss on ignition.

Ref. Mat., Reference materials were BCR-2 for major elements and JA-1 for trace elements.

subduction of the Izanagi Plate within the proto-Pacific Ocean after the Early Cretaceous (Aptian-Albian, 125$101 \mathrm{Ma}$ ), and they were eventually accreted onto the Paleo-Kuril arc-trench system at 57-48 Ma to form an allochthonous block as part of the mélange facies of the Hiroo Complex on the landward slope of the trench (Fig. 7a). Thus, it is concluded that Type 1 and Type 3 greenstones have recorded igneous processes on the Iza- nagi Plate that was being subducted during the formation of the subduction complex of the Hidaka belt.

Type 2 greenstone is interpreted as a product of a spreading axis that was active during the formation of the subduction complex of the Hidaka belt (Fig. 7b). Type 2 greenstone is accompanied by Besshi-type massive sulfide deposits in some areas (e.g., Mariko, 1984; Miyake, 1988; Nakayama, 2003), and a Re-Os isochron age of 
Table 1. (Continued)

\begin{tabular}{|c|c|c|c|c|c|}
\hline & \multicolumn{4}{|c|}{ Type 2} & Ref. \\
\hline Sample & UE-01 & UE-02 & OC-01 & FR-01 & Mat. \\
\hline $\mathrm{SiO}_{2}$ & 53.74 & 53.79 & 52.99 & 51.02 & 53.89 \\
\hline $\mathrm{TiO}_{2}$ & 1.77 & 1.84 & 1.26 & 0.98 & 2.30 \\
\hline $\mathrm{Al}_{2} \mathrm{O}_{3}$ & 14.92 & 14.93 & 16.97 & 17.19 & 13.71 \\
\hline $\mathrm{Fe}_{2} \mathrm{O}_{3}{ }^{*}$ & 10.01 & 10.82 & 7.50 & 8.55 & 13.86 \\
\hline $\mathrm{MnO}$ & 0.15 & 0.15 & 0.14 & 0.15 & 0.19 \\
\hline $\mathrm{MgO}$ & 6.50 & 6.13 & 8.35 & 7.99 & 3.60 \\
\hline $\mathrm{CaO}$ & 7.68 & 6.54 & 8.15 & 10.82 & 7.13 \\
\hline $\mathrm{Na}_{2} \mathrm{O}$ & 5.40 & 5.65 & 3.42 & 3.50 & 3.20 \\
\hline $\mathrm{K}_{2} \mathrm{O}$ & 0.17 & 0.39 & 1.17 & 0.09 & 1.79 \\
\hline $\mathrm{P}_{2} \mathrm{O}_{5}$ & 0.16 & 0.20 & 0.21 & 0.08 & 0.35 \\
\hline Total & 100.50 & 100.45 & 100.17 & 100.35 & 100.02 \\
\hline LOI & 3.43 & 3.07 & 3.43 & 0.69 & - \\
\hline $\mathrm{Ti}$ & 10273 & 10046 & 7006 & 5492 & 4929 \\
\hline V & 295 & 282 & 170 & 212 & 105 \\
\hline $\mathrm{Cr}$ & 138.1 & 119.8 & 292.0 & 363.6 & 4.6 \\
\hline $\mathrm{Ni}$ & 101 & 178 & 207 & 82 & 3 \\
\hline $\mathrm{Zn}$ & 95.1 & 83.6 & 61.8 & 61.5 & 89.8 \\
\hline $\mathrm{Rb}$ & 7.73 & 10.01 & 17.70 & 6.25 & 11.97 \\
\hline $\mathrm{Sr}$ & 426 & 340 & 248 & 261 & 253 \\
\hline Y & 38.1 & 36.4 & 20.8 & 19.4 & 29.5 \\
\hline $\mathrm{Zr}$ & 110.8 & 137.8 & 127.3 & 52.9 & 81.3 \\
\hline $\mathrm{Nb}$ & 2.11 & 3.71 & 6.38 & 0.44 & 1.29 \\
\hline $\mathrm{Ba}$ & 53 & 104 & 448 & 28 & 317 \\
\hline $\mathrm{La}$ & 7.15 & 13.87 & 10.96 & 4.52 & 5.66 \\
\hline $\mathrm{Ce}$ & 13.2 & 17.3 & 21.0 & 5.3 & 12.9 \\
\hline $\operatorname{Pr}$ & 2.56 & 3.03 & 2.90 & 1.20 & 1.64 \\
\hline $\mathrm{Nd}$ & 10.7 & 11.9 & 11.8 & 5.8 & 10.8 \\
\hline $\mathrm{Sm}$ & 4.77 & 6.24 & 4.07 & 2.25 & 3.21 \\
\hline $\mathrm{Eu}$ & 1.4 & 2.1 & 1.2 & 0.8 & 1.3 \\
\hline Gd & 5.82 & 6.70 & 4.64 & 4.00 & 4.31 \\
\hline $\mathrm{Tb}$ & 0.80 & 1.29 & 0.51 & 0.34 & 0.60 \\
\hline Dy & 6.78 & 6.57 & 3.92 & 3.47 & 3.91 \\
\hline Ho & 1.15 & 1.22 & 0.65 & 0.63 & 1.09 \\
\hline Er & 6.50 & 5.03 & 2.35 & 3.53 & 3.27 \\
\hline $\mathrm{Tm}$ & 0.66 & 0.63 & 0.37 & 0.30 & 0.41 \\
\hline $\mathrm{Yb}$ & 4.08 & 5.25 & 3.29 & 3.66 & 3.27 \\
\hline $\mathrm{Lu}$ & 0.52 & 0.60 & 0.35 & 0.33 & 0.48 \\
\hline Hf & 3.20 & 7.74 & 3.23 & 1.61 & 2.34 \\
\hline $\mathrm{Ta}$ & 0.54 & 0.66 & 0.86 & 0.20 & 0.12 \\
\hline $\mathrm{Pb}$ & 0.75 & 1.37 & 2.24 & 0.39 & 4.67 \\
\hline Th & 0.57 & 1.41 & 2.06 & 0.03 & 0.83 \\
\hline $\mathrm{U}$ & 0.07 & 0.31 & 0.65 & 0.12 & 0.33 \\
\hline
\end{tabular}

Samples are from the Hidaka belt and comparison with reference materials.

$\mathrm{Fe}_{2} \mathrm{O}_{3}{ }^{*}$ denotes total $\mathrm{Fe}$ as $\mathrm{Fe}_{2} \mathrm{O}_{3}$ and LOI denotes loss on ignition.

Ref. Mat., Reference materials were BCR-2 for major elements and JA-1 for trace elements.

$48.0 \pm 0.6 \mathrm{Ma}$ has been reported for samples from this ore (Nozaki et al., 2011a, b). In general, the Besshi-type massive sulfide deposit is regarded as a block of submarine hydrothermal ore deposit within the subduction complex and originally formed at the spreading axis (mid-

\begin{tabular}{|ll|}
\hline Type 1 & Type 2 \\
$\triangle$ This study & $\diamond$ This study \\
$\triangle$ Tachiiwa block & $\diamond$ Shimokawa area \\
$\Delta$ Nikoro Group & $\diamond$ Okutokachi area \\
& $\diamond$ Hidaka metamorphic belt \\
Type 3 & $\diamond$ Hidaka Supergroup \\
& \\
\hline
\end{tabular}

$\mathrm{V}(\mathrm{ppm})$

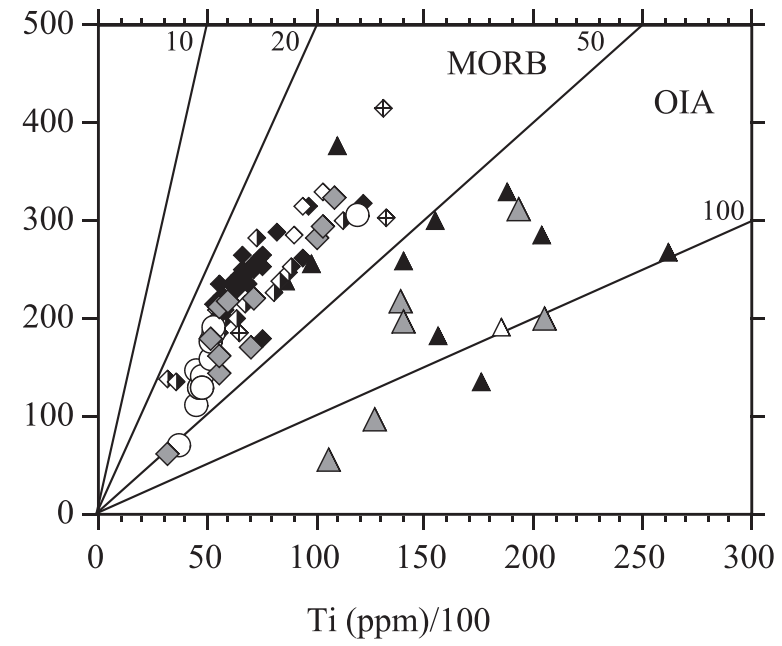

Figure 4. $\mathrm{Ti} / \mathrm{V}$ chart for greenstones in the Hidaka belt. Data for the rocks in the Tachiiwa block are from Owada et al. (1992), Nikoro Group are OIB-type basalts from Sakai et al. (2019), Shimokawa area rocks are from Kawanami et al. (2006), Okutokachi area rocks are from Yamasaki et al. (2018), Hidaka metamorphic belt rocks are from Mikoshiba-Ujiie (1999) and Kawanami et al. (2006), Hidaka Supergroup rocks are from Miyashita and Kiminami (1999), and the Daimaruyama mass is from Yamasaki and Nanayama (2018). The fields of different tectonic settings are after Shervais (1982). OIA, ocean island and alkalic basalts; MORB, mid-ocean ridge basalt.

ocean ridge). The lithological types, mode of occurrence, and geochemical characteristics, including isotopic compositions of host rocks, suggest that the ore deposit was formed sufficiently close to a continent or island arc to receive significant volumes of terrigenous sediment (e.g., Kase, 2003; Isozaki and Nakayama, 2003; Nozaki, 2015). Therefore, the timing of the formation of the Besshi-type massive sulfide deposit in the Hidaka belt is restricted to the period during which the spreading axis was located close to the subduction zone, and the age of ores was nearly the same as the age of extrusion and intrusion of the in-situ greenstone just before the subduction (Fig. 7b). Recent reconstructions of global plate motions suggest that the Izanagi Plate was being subducted along the eastern margin of Eurasia from 230 to $60 \mathrm{Ma}$, and that the Izanagi-Pacific ridge, which was oriented 

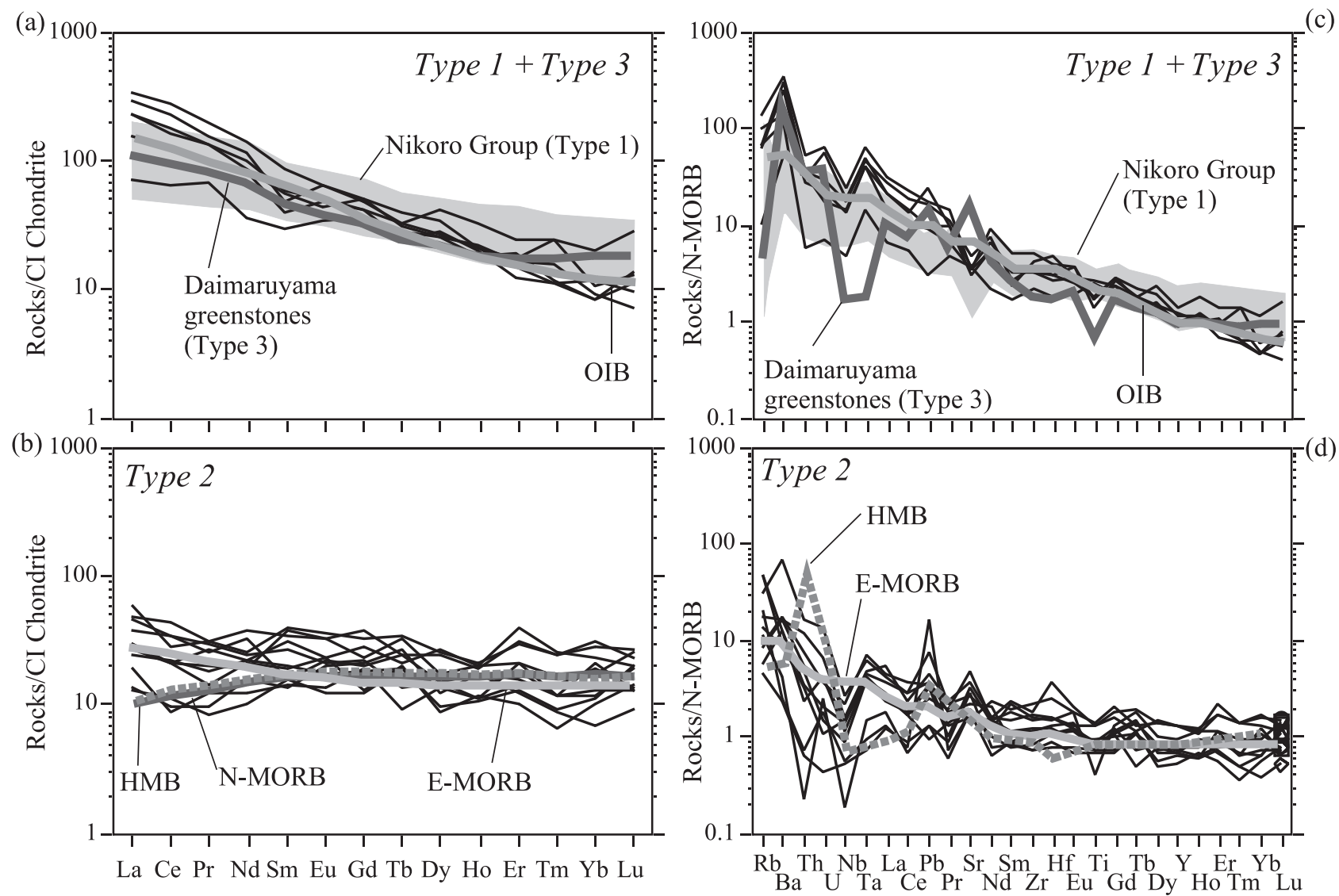

Figure 5. Whole-rock trace element patterns for greenstones in the Hidaka belt and reference rocks. Panels (a) and (b) are chondrite-normalized and (c) and (d) are normal mid-ocean basalt (N-MORB)-normalized. Chondrite and N-MORB values are from Sun and McDonough (1989). (a) and (c) Type 1 and Type 3 greenstones in the Hidaka belt, greenstone in the Nikoro Group (equivalent to Type 1), and ocean island basalt (OIB). OIB values are from Sun and McDonough (1989). Data for the rocks in the Nikoro Group are OIB-type basalts from Sakai et al. (2019). (b) and (d) Type 2 greenstone in the Hidaka belt, amphibolites in the Hidaka metamorphic belt (HMB), N-MORB, and enriched-type MORB (E-MORB). E-MORB values are from Sun and McDonough (1989). The amphibolite value in the Hidaka metamorphic belt is an average value from Mikoshiba-Ujiie (1999) and Kawanami et al. (2006).

subparallel to the trench, was subducted around $50 \mathrm{Ma}$ (Seton et al., 2015; Müller et al., 2016). This independent estimation of the timing of the ridge subduction is very much in agreement with the estimated formation age of the Besshi-type massive sulfide ore deposit.

The E-MORB-like geochemical features of Type 2 greenstone are somewhat questionable, because it is difficult to assume a plume influence during the ridge-subduction event. Miyazaki et al. (2015) suggested that oceanic plates formed by the Izanagi-Pacific ridge later than $80 \mathrm{Ma}$ had $\mathrm{Pb}-\mathrm{Nd}-\mathrm{Hf}$ isotopic signatures of Indian mantle rather than Pacific mantle-type isotopic signatures with $>80$ Ma oceanic plates. This means that the boundary of $\mathrm{Pb}-\mathrm{Nd}-\mathrm{Hf}$ isotopic signatures of Indian and Pacific mantle lies north and south, respectively, in the upper mantle of the northwest Pacific Ocean (Miyazaki et al., 2015). As a result, young (6 Ma) petit-spot basalts (Hirano et al., 2006) erupted on the outer rise of Japan Trench, which is located along the western margins of the $140 \mathrm{Ma}$
Pacific Plate, show an Indian mantle-like isotopic composition (Machida et al., 2009; Miyazaki et al., 2015). The subduction of the Izanagi-Pacific ridge is assumed around $48 \mathrm{Ma}$, as mentioned above; thus, Type 2 greenstone presumably was generated from upper mantle with an Indian mantle-like isotopic signature. Although the relationship between the isotopic composition and geochemical composition of source mantle is not straightforward, it is known that modern Indian Ocean MORB has had unique and different geochemical features relative to Pacific and Atlantic Ocean MORBs (e.g., Natland, 1991; Langmuir et al., 1992; Sato et al., 2008, and references therein). Figure $8 \mathrm{a}$ compares the REE patterns between Type 2 greenstone and modern Indian MORB from the southwest Indian Ridge. The Indian MORB characterized by relatively flat REE patterns is compared to "typical" Pacific and Atlantic N-MORBs (see Fig. 5 for the representative composition of N-MORB). Trace element compositions of Type 2 greenstones and modern Indian 

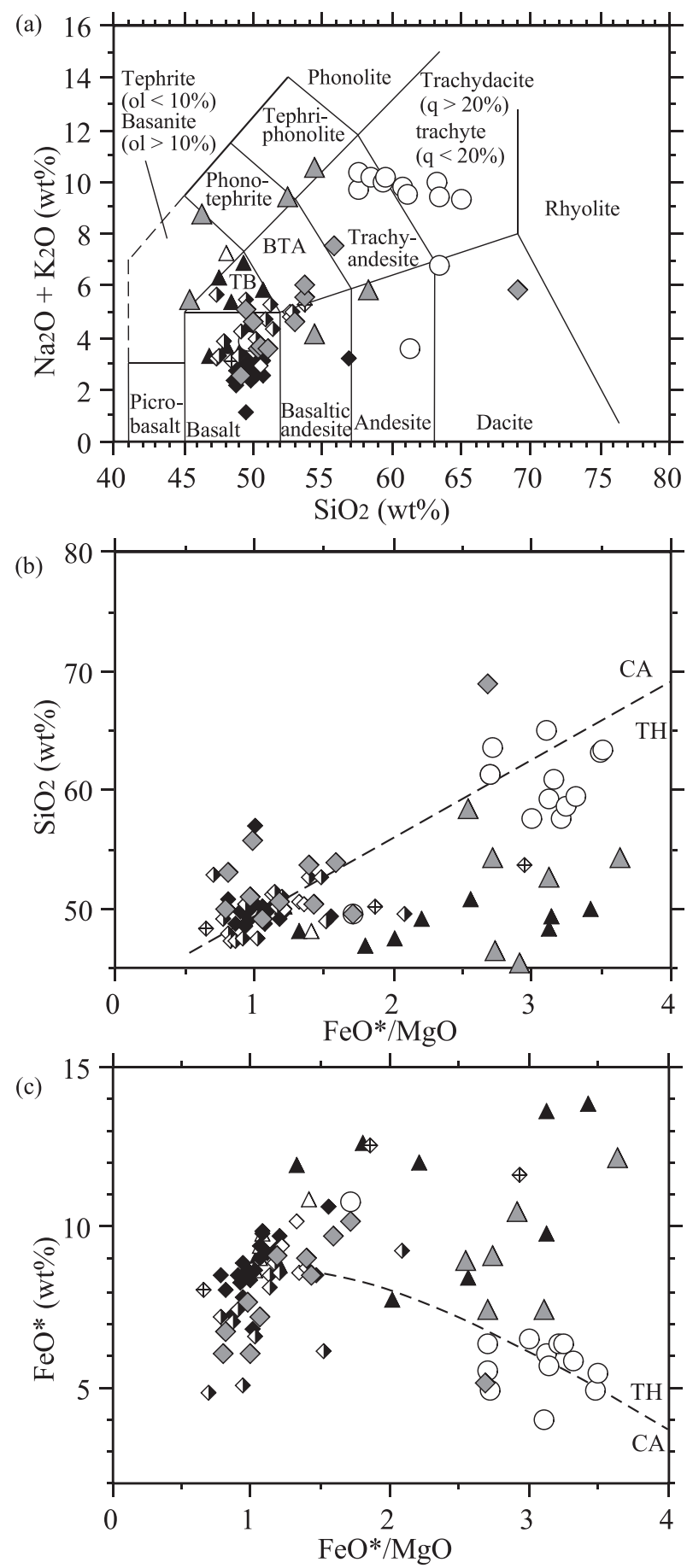

Figure 6. Volcanic classification diagrams for greenstones in the Hidaka belt and reference rocks showing (a) total alkali- $\mathrm{SiO}_{2}$, (b) $\mathrm{SiO}_{2}-\mathrm{FeO}^{*} / \mathrm{MgO}$, and (c) $\mathrm{FeO}^{*}-\mathrm{FeO}^{*} / \mathrm{MgO}$. Panel (a) is after Le Maitre et al. (2002). CA-TH boundaries in panels (b) and (c) are from Miyashiro (1974). CA, calc-alkaline; TH, tholeiite; TB, trachybasalt; BTA, basaltic trachyandesite. Symbols and sources of the compiled data are the same as for Figure 4.

Ocean MORBs are plotted in the N-MORB to volcanic arc and within-plate basalt fields on the $2 \mathrm{Nb}-\mathrm{Zr} / 4-\mathrm{Y}$ discrimination diagram (Meschede, 1986), and none of the
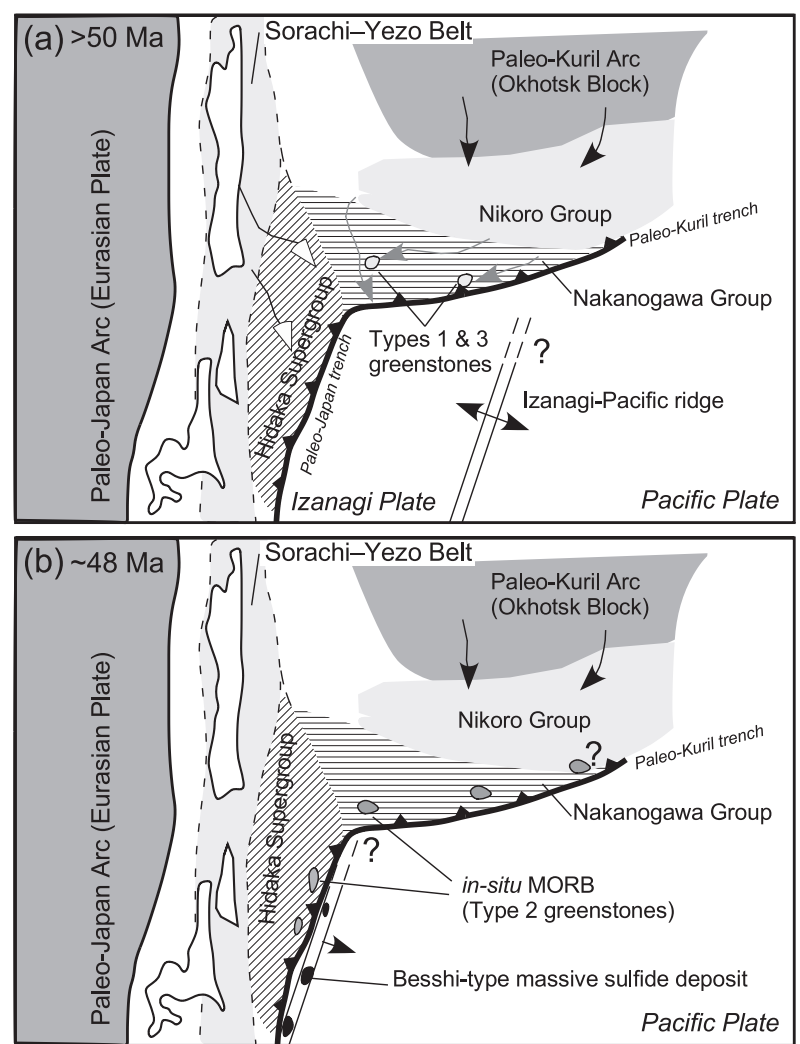

Figure 7. Conceptual models of paleogeographic reconstruction of the Hokkaido region showing the accretion location of each type of greenstone. (a) Pre-50 Ma. (b) $\sim 48 \mathrm{Ma}$. The model is adapted from Nanayama et al. (1993). Direction and positions of the Izanagi-Pacific ridge are after Müller et al. (2016). Curved arrows denote directions of supply of sediments and allochthonous blocks. See text for detailed explanation.

compositions are plotted within the E-MORB field (Fig. $8 b)$. Overall discussions suggest that MORB generation from upper mantle with an Indian mantle composition during the Izanagi-Pacific ridge subduction in the western margins of the Pacific Ocean is probably a fundamental cause of the E-MORB-like multi-trace element composition of Type 2 greenstone.

As mentioned above, Nanayama (1992a) and Yamasaki and Nanayama (2018) concluded that the greenstone blocks corresponding to Type 1 and Type 3 were allochthonous blocks directly derived from the Nikoro Group, Tokoro belt, which were formed in the subduction complex of the paleo-Kuril arc-trench system (Fig. 7a). Because the zircon $\mathrm{U}-\mathrm{Pb}$ age of sandstones in the Nakanogawa Group indicates a depositional age of $64.4 \pm 1.0-$ $48.0 \pm 0.4 \mathrm{Ma}$ (Nanayama et al., 2019), they assumed that two subduction complexes, namely the paleo-Japan arc-trench system and paleo-Kuril arc-trench system, were located close together during this period. The youngest depositional age of the Nakanogawa Group also coincides with the formation age of the Besshi-type mas- 
(a)

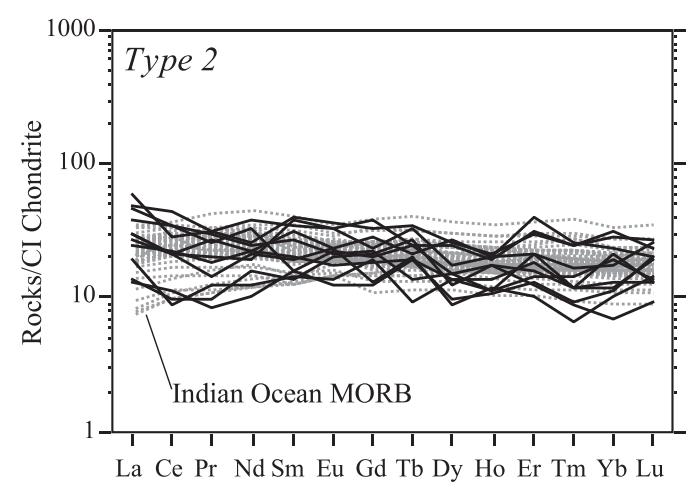

(b)

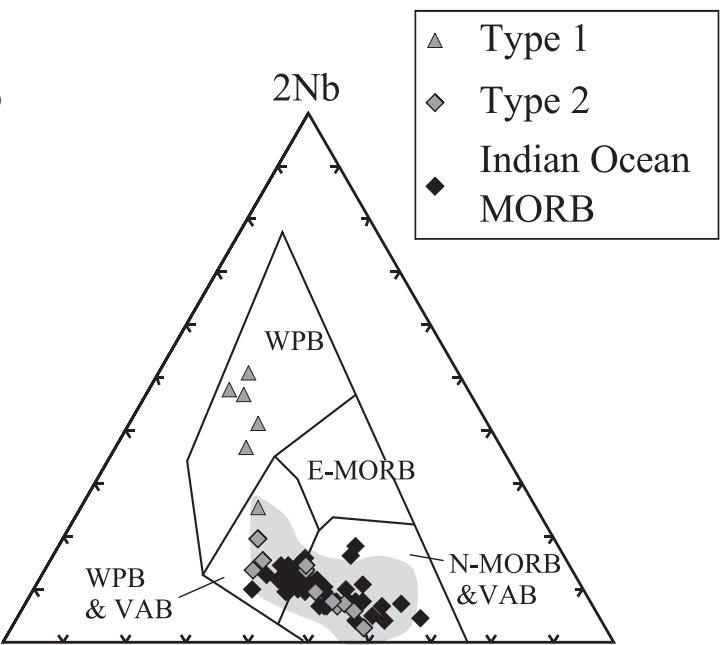

$\mathrm{Zr} / 4$

Y

Figure 8. Comparison of trace-element compositions between Type 2 greenstones and modern Indian Ocean MORB. (a) CI chondrite-normalized whole-rock REE patterns of the Type 2 greenstones and modern Indian Ocean MORB. (b) Discrimination diagram of $2 \mathrm{Nb}-\mathrm{Zr} / 4-\mathrm{Y}$ after Meschede (1986). Composition of Type 1 greenstone is also plotted as a reference. Gray field is the compositional range of amphibolites in the Hidaka metamorphic belt and greenstones in the Hidaka Supergroup reported by Kawanami et al. (2006). The fields of different tectonic settings are after Shervais (1982). VAB, volcanic arc basalts; WPB, within-plate basalts. See text for detailed discussion. Data sources for the modern Indian Ocean MORBs are Coogan et al. (2004), Paquet et al. (2016), and Li et al. (2019).

sive sulfide deposit in the Hidaka Supergroup; thus, such a close geographical relationship between two subduction systems inevitably requires the existence of in-situ greenstone within the Nikoro Group, Tokoro belt. In contrast, contemporaneous formation of two subduction complexes in the Hidaka and Tokoro belts suggests subduction of the same paleo-Pacific plate into both trenches. Therefore, it can also be assumed that the Type 1 and Type 3 greenstones on the paleo-Pacific plate were accreted to both subduction complexes. However, distribu- tions of those types of greenstones have been limited in the Nakanogawa Group, southern Hidaka belt. This maldistribution of the greenstone, that is, the absence of Type 1 and Type 3 greenstones in the northern Hidaka Supergroup, implies a difference in provenance between the Hidaka Supergroup and Nakanogawa Group (Fig. 7a), as mentioned in earlier studies (Nanayama, 1992a; Nanayama et al., 1993).

Based on results of this study, the existence of MORB-type greenstone that was previously restricted to the Hidaka Supergroup, northern Hidaka belt, was confirmed in the Hiroo Complex, Nakanogawa Group, in the southern Hidaka belt. However, the volume of greenstone in the Nakanogawa Group is quite small relative to that in the Hidaka Supergroup, and furthermore, existence of insitu greenstone has never been reported for the Nakanogawa Group (e.g., Nanayama, 1992b; Nanayama et al., 1993). In the southern Hidaka belt, rocks that correspond to MORB-type greenstone in the Hidaka Supergroup have been assumed as amphibolites in the HMB (e.g., Komatsu, 1985; Osanai et al., 1989; Kawanami et al., 2006). In the HMB, most of the amphibolites show typical N-MORB trace element and isotopic compositions (Mikoshiba-Ujiie, 1999; Kawanami et al., 2006; Yamasaki et al., 2018), whereas occurrence of E-MORB-like amphibolites from the southern part of the HMB has been reported to be rare (Kawanami et al., 2006). Therefore, whole-rock geochemistry of amphibolites in the HMB is different than that of the Type 2 greenstone in this study as a whole.

Plutonic rock in the Hidaka belt is called the Hidaka Magmatic Zone (Maeda et al., 1986; Maeda, 1990, 1997). $\mathrm{U}-\mathrm{Pb}$ zircon dating of some granitic bodies that intruded into the Hidaka Supergroup yields an age of 46-45 Ma (Jahn et al., 2014), and the granites brought contact metamorphism to the rocks of the Hidaka Supergroup, including the in-situ greenstone (i.e., Type 2 greenstone) (Miyashita et al., 1997). The age of the granitic rock is slightly younger than the depositional age of the Nakanogawa Group and formation age of the Besshi-type massive sulfide deposit in the Hidaka Supergroup ( $48 \mathrm{Ma})$. Although the zircon $\mathrm{U}-\mathrm{Pb}$ age of 46-45 Ma has not been reported for plutonic rock in the southern Hidaka belt, a $\mathrm{K}$-Ar biotite age of $\sim 45 \mathrm{Ma}$ has been reported for granitic gravel in the Miocene Toyonigawa Formation, which is located in the eastern HMB (Arita et al., 2001). Yamasaki et al. (2018) used a comparison between the geochemical features of those granitic gravels and the granitic rocks in the northern Hidaka belt (Hidaka Magmatic Zone) to suggest that granitic rocks of 46-45 Ma had existed in the southern Hidaka belt, but they eroded away due to uprising of the Hidaka Mountains. Based on the above inter- 
pretations, the granitic rocks of 46-45 Ma in the southern Hidaka belt probably also intruded into the in-situ greenstone, as in the case of northern Hidaka belt, but both of them were eroded away by exhumation of the HMB. Therefore, amphibolites in the HMB should have been located under the in-situ greenstone in the southern Hidaka belt and have neither equivalent lithology nor contemporaneous magmatic products of Type 2 greenstone. Probably, the N-MORB amphibolite in the HMB is a fragment of an oceanic plate formed in $>80 \mathrm{Ma}$ derived from Pacific mantle and consumed prior to initiation of the magmatic activity that formed Type 2 greenstone.

Interpretation of the geochemical data for greenstone from the whole Hidaka belt in this study, combined with information on geology and ages from the literature, painted a more precise picture of the geodynamic setting of the subduction complex of the Hidaka belt, which coherently explains the origin of greenstones and the Izanagi-Pacific ridge subduction (Fig. 7). However, some problems still need to be solved to clarify the whole picture. Ridge subduction is one of the first-order large geologic events on Earth, but direct evidence is limited only to the in-situ MORB (greenstone) in the Hidaka Supergroup. Because the ages of plutonic rocks in the northern Hidaka belt (Hidaka Magmatic Zone) are close to this geologic event, as discussed above, it might be related to ridge subduction. However, the whole-rock geochemistry of those granites is similar to that of plutonic rocks from later stages ( 37 and $19 \mathrm{Ma})$ of the Hidaka belt (Jahn et al., 2014; Yamasaki et al., 2018). Thus, it is strongly suggested that clastic and/or crustal rocks in the Hidaka belt are common source materials for those granitic rocks in the Hidaka belt, at least from 46 to 19 Ma. Some magmatic responses to ridge subduction, such as in-situ MORB and/or adakitic rocks (e.g., Thorkelson and Breitsprecher, 2005; Lomize and Luchitskaya, 2012, and references therein), are expected, even in the paleoKuril arc-trench system (Tokoro and Nemuro belts), as well as the Hidaka belt (Fig. 7). Confirmation and evaluation of such lithological distributions in central to eastern Hokkaido are important problems for future research to reconstruct the precise tectonic history of the northeastern margin of the Eurasian plate from Cretaceous to Paleogene times.

\section{ACKNOWLEDGMENTS}

The authors are thankful to Akira Owada, Takumi Sato, Eri Hirabayashi, and Kazuyuki Fukuda for preparing the thin sections. Thoughtful reviews and comments by Nobuhiko Nakano and Atsushi Kamei significantly improved the manuscript. This work was supported by JSPS
KAKENHI Grant Nos. JP16K05585 and JP19K04025.

\section{REFERENCES}

Arita, K., Ganzawa, Y. and Itaya, T. (2001) Tectonics and uplift processes of the Hidaka Mountains, Hokkaido, Japan inferred from thermochronology. Bulletin of the Earthquake Research Institute, The University of Tokyo, 76, 93-104.

Arita, K., Maeda, J. and Niida, K. (2003) Deep-seated plutonic and metamorphic rocks of the Hidaka mountains, Hokkaido. IUGG2003 Field Trip Guidebook C2, The Volcanological Society of Japan, 1-44.

Coogan, L.A., Thompson, G.M., MacLeod, C.J., Dick, H.J.B., et al. (2004) A combined basalt and peridotite perspective on 14 million years of melt generation at the Atlantis Bank segment of the Southwest Indian Ridge: evidence for temporal changes in mantle dynamics? Chemical Geology, 207, 13-30.

Hasegawa, K., Osanai, H., Suzuki, M. and Matsushita, K. (1961) Pre-Yezo Group in the axial zone of Hokkaido - Proposal on the classification of the Group-. Report of the Geological Survey of Hokkaido 25, 108-114 (in Japanese with English abstract).

Hirano, N., Takahashi, E., Yamamoto, J., Abe, N., Ingle, S.P., Kaneoka, I., Hirata, T., Kimura, J.-I., Ishii, T., Ogawa, Y., Machida, S. and Suyehiro, K. (2006) Volcanism in response to plate flexure. Science, 313, 1426-1428.

Isozaki, Y. and Nakayama, T. (2003) I-B4 Tectonic setting of the Besshi-type ore deposits. In Resource Environmental Geology (Shikazono, N., Nakano, T. and Hasyashi, K. Eds.). The Society of Resource Geology, 95-100 (in Japanese).

Jahn, B.-M., Usuki, M., Usuki, T. and Chung, S.-L. (2014) Generation of Cenozoic granitoids in Hokkaido (Japan): Constraints from zircon geochronology, $\mathrm{Sr}-\mathrm{Nd}-\mathrm{Hf}$ isotopic and geochemical analyses, and implications for crustal growth. American Journal of Science, 314, 704-750.

Kase, K. (2003) Origin and classification of the Besshi-type ore deposits. In Resource Environmental Geology (Shikazono, N., Nakano, T. and Hasyashi, K. Eds.). The Society of Resource Geology, 87-94 (in Japanese).

Kawamura, M., Tajika, J., Kawamura, T. and Kato, Y. (1986) Constitution and occurrences of the Paleozoic and Mesozoic formations in S. W. Hokkaido, northern Japan. Monograph of the Association for the Geological Collaboration in Japan, 31, 1732 (in Japanese with English abstract).

Kawanami, S., Nakano, N., Osanai, Y., Kagami, H. and Owada, M. (2006) Protoliths of the high-grade amphibolites from the Main Zone of the Hidaka metamorphic belt in Hokkaido, northern Japan and comparison with greenstones in the northern Hidaka belt. The Journal of the Geological Society of Japan, 112, 639-653 (in Japanese with English abstract).

Kemp, A I.S., Shimura, T., Hawkesworth, C.J. and EIMF (2007) Linking granulites, silicic magmatism, and crustal growth in arcs: Ion microprobe (zircon) $\mathrm{U}-\mathrm{Pb}$ ages from the Hidaka metamorphic belt, Japan. Geology, 35, 807-810.

Kiminami, K. (1986) Cretaceous tectonics of Hokkaido and the environments of the Okhotsk Sea. Monograph of the Association for the Geological Collaboration in Japan, 31, 403-418 (in Japanese with English abstract).

Kiminami, K. and Kontani, Y. (1983) Mesozoic arc-trench systems in Hokkaido Japan. In Accretion Tectonics in the Circus-Pacific Regions (Hashimoto, M. and Uyeda, S. Eds.). Terrapub, Tokyo, 107-122. 
Kiminami, K., Miyashita, S., Kimura, G., Tajika, J., et al. (1986) Mesozoic rocks in the Hidaka belt - Hidaka Supergroup. Monograph of the Association for the Geological Collaboration in Japan, 31, 137-155 (in Japanese with English abstract).

Kiminami, K., Miyashita, S. and Kawabata, K. (1999) Occurrence and significance of in-situ basaltic rocks from the Rurochi Formation in the Hidaka Supergroup, northern Hokkaido, Japan. The Memoirs of the Geological Society of Japan, 52, 103-12 (in Japanese with English abstract).

Komatsu, M. (1985) Structural framework of the axial zone in Hokkaido - its composition, characters and tectonics-. The Memoirs of the Geological Society of Japan, 25, 137-155 (in Japanese with English abstract).

Komatsu, M., Osanai, Y., Toyoshima, T. and Miyashita, S. (1989) Evolution of the Hidaka Metamorphic Belt, Northern Japan. Geological Society Special Publication, 43, 487-493.

Kontani, Y., Kiminami, K., Tajika, J. and Maniwa, K. (1986) Cretaceous sedimentary rocks in the Tokoro and Nemuro belts, Hokkaido. Monograph of the Association for the Geological Collaboration in Japan, 31, 157-171 (in Japanese with English abstract).

Langmuir, C.H., Klien, E.M. and Plank, T. (1992) Petrological systematics of mid-ocean ridge basalts: Constraints on melt generation beneath ocean ridges. In Mantle Flow and Melt Generation at Mid-Ocean Ridges (Morgan, J.P., Blackman, D.K. and Sinton, J.M. Eds.). Geophysical Monograph Series, AGU, 71, 183-280.

Le Maitre, R.W., Streckeisen, A., Zanettin, B., Le Bas, M.J., et al. (2002) Igneous Rocks, A Classification and Glossary of Terms, 2nd ed. pp. 236, Cambridge University Press, Cambridge.

Li, W., Tao, C., Zhang, W., Liu, J., et al. (2019) Melt Inclusions in Plagioclase Macrocrysts at Mount Jourdanne, Southwest Indian Ridge $\left(\sim 64^{\circ} \mathrm{E}\right)$ : Implications for an Enriched Mantle Source and Shallow Magmatic Processes. Minerals, 9, 493; doi:10.3390/min 9080493 .

Lomize, M.G. and Luchitskaya, M.V. (2012) Subduction of spreading ridges as a factor in the evolution of continental margins. Geotectonics, 46, 47-68.

Machida, S., Hirano, N. and Kimura, J.-I. (2009) Evidence for recycled plate material in Pacific upper mantle unrelated to plumes. Geochimica et Cosmochimica Acta, 73, 3028-3037.

Maeda, J. (1990) Opening of the Kuril Basin deduced from the magmatic history of Central Hokkaido, North Japan. Tectonophysics, 174, 235-255.

Maeda, J. (1997) Magmatic processes observed in a cross section of juvenile continental crust exposed in the Hidaka Mountains, Hokkaido, Japan. Bulletin of the Volcanological Society of Japan, 42, S107-S121 (in Japanese with English abstract).

Maeda, J. and Kagami, H. (1996) Interaction of a spreading ridge and an accretionary prism: Implications from MORB magmatism in the Hidaka magmatic zone, Hokkaido, Japan. Geology, 24, 31-34.

Maeda, J., Suetake, S., Ikeda, Y., Tomura, S., et al. (1986) Tertiary plutonic rocks in the axial zone of Hokkaido - distribution, age, major element chemistry, and tectonics-. Monograph of the Association for the Geological Collaboration in Japan, 31, 223-246 (in Japanese with English abstract).

Mariko, T. (1984) Sub-sea hydrothermal alteration of basalt, diabase and sedimentary rocks in the Shimokawa copper mining area, Hokkaido, Japan. Mining Geology, 34, 307-321.

Meschede, M. (1986) A method of discriminating between differ- ent types of mid-ocean ridge basalts and continental tholeiites with the $\mathrm{Nb}-\mathrm{Zr}-\mathrm{Y}$ diagram. Chemical Geology, 56, 207-218.

Mikoshiba-Ujiie, M. (1999) Chemical characteristics of basic metamorphic rocks from the Main Zone of the Hidaka metamorphic belt, Hokkaido: an affinity to mid-ocean ridge basalts. Bulletin of the Geological Survey of Japan, 50, 613-634 (in Japanese with English abstract).

Miyake, T. (1988) Geology and mineralization of the Shimokawa mine: An allochtonous ridge-type massive sulfide ore deposit. Mining Geology, 34, 307-321.

Miyashiro, A. (1974) Volcanic rock series in island arcs and active continental margins. American Journal of Science, 274, 321355.

Miyashita, S. and Katsushima, T. (1986) The Tomuraushi greenstone complex of the central Hidaka zone: Contemporaneous occurrence of abyssal tholeiite and terrigenous sediments. The Journal of the Geological Society of Japan, 92, 535-557.

Miyashita, S. and Kiminami, K. (1999) Petrology of the grteenstones in the Rurochi Formation in the northern Hidaka Belt, Hokkaido. The Memoirs of the Geological Society of Japan, 52, 113-124 (in Japanese with English abstract).

Miyashita, S. and Yoshida, A. (1994) Geology and petrology of the Shimokawa ophiolite (Hokkaido, Japan): ophiolite possibly generated near R-T-T triple junction. In Circum-Pacific ophiolites (Ishiwatari, A. et al., eds.). Proceedings of $29^{\text {th }}$ IGC Ophiolite symposium, Part D, VSP publications, Netherlands, 163-182.

Miyashita, S., Arai, T. and Nagahashi, T. (1997) Significance of greenstones in the Hidaka belt, Hokkaido: Evidence for polycollision of ocean ridges. The Memoirs of the Geological Society of Japan, 47, 307-323 (in Japanese with English abstract).

Miyazaki, T., Kimura, J.-I., Senda, R., Vaglarov, B.S., et al. (2015) Missing western half of the Pacific Plate: Geochemical nature of the Izanagi-Pacific Ridge interaction with a stationary boundary between the Indian and Pacific mantles. Geochemistry, Geophysics, Geosystems, 16, 3309-3332, doi:10.1002/ 2015 GC005911.

Müller, R.D., Seton, M., Zahirovic, S., Williams, S.E., et al. (2016) Ocean basin evolution and global-scale plate reorganization events since Pangea breakup. Annual Reviews of Earth and Planetary Sciences, 44, 107-38.

Nakayama, K. (2003) Internal structure of the Shimokawa greenstone-argillaceous sediment complex-Reconstruction of the paleo-sedimented spreading center-. Shigen Chishitsu, 53, 81-94 (in Japanese with English abstract).

Nanayama, F. (1992a) Three petroprovinces identified in the Nakanogawa Group, Hidaka Belt, central Hokkaido, Japan, and their geotectonic significance. The Memoirs of the Geological Society of Japan, 38, 27-42 (in Japanese with English abstract).

Nanayama (1992b) Stratigraphy and facies of the Paleocene Nakanogawa Group in the southern part of central Hokkaido, Japan. The Journal of the Geological Society of Japan, 98, 1041-1059 (in Japanese with English abstract).

Nanayama, F., Kanamatsu, T. and Fujiwara, Y. (1993) Sedimentary petrology and paleotectonic analysis of the arc-arc junction: the Paleocene Nakanogawa Group in the Hidaka Belt, central Hoikkaido, Japan. Palaeogeography, Palaeoclinatology, Palaeoecology, 105, 53-69.

Nanayama, F., Takahashi, Y., Yamasaki, T., Nakagawa, M., et al. (2018) U-Pb zircon ages of the Nakanogawa Group in the 
Hidaka Belt, northern Japan: Implications for its provenance and the protolith of the Hidaka metamorphic rocks. Island Arc, doi:10.1111/iar.12234.

Nanayama, F., Yamasaki, T., Iwano, H., Danhara, T. and Hirata, T. (2019) Zircon U-Pb ages of sedimentary complexes in the Hidaka Belt: New age data on the northern, southern, and western areas of the Paleogene Nakanogawa Group, central Hokkaido, northern Japan. The Journal of the Geological Society of Japan, 125, 421-438.

Natland, J. (1991) Indian oceanic crust. In Oceanic Basalts (Floyd, P. A. Ed.), Blackie \& Son Ltd., 289-310.

Niida, K. and Kito, N. (1986) Cretaceous arc-trench systems in Hokkaido. Monograph of the Association for the Geological Collaboration in Japan, 31, 379-402 (in Japanese with English abstract).

Nozaki, T. (2015) Metallogenic study of Besshi-type volcanogenic massive sulfide deposit using a Re-Os dating method. Chikyukagaku (Geochemistry), 49, 65-78 (in Japanese with English abstract)

Nozaki, T., Kato, Y., Suzuki, K., Takaya, Y. and Nakayama, K. (2011a) Re-Os ages of the Shimokawa and Makimine Besshitype massive sulfide deposits: New age constraints for a timing of the Kula Ridge subduction into the paleo-Japanese Island. Abstracts with programs of the 61th Annual Meeting of the Society of Resource Geology, 60 (in Japanese).

Nozaki, T., Kato, Y., Suzuki, K., Takaya, Y. and Nakayama, K. (2011b) Re-Os ages of Besshi-type massive sulfide deposits associated with in situ basalt as a new age constraint for ridge subduction. Abstracts of Goldschmidt Conference 2011, Mineralogical Magazine, 75, 1553

Osanai, Y, Owada, M. and Takasu, I. (1989) Original rock constitution of the Main Zone of the Hidaka metamorphic belt, Hokkaido, Japan. Bulletin of Fukuoka University of Education. Part 3, Natural sciences, 38, 71-91 (in Japanese with English abstract).

Osanai, Y., Komatsu, M. and Owada, M. (1991) Metamorphism and granite genesis in the Hidaka Metamorphic Belt, Hokkaido, Japan. Journal of Metamorphic Geology, 9, 111-124.

Owada, M., Nanayama, F., Shimura, T. and Osanai, Y. (1992) Lamprophyre from the Nakanogawa group in the central zone of Hokkaido, northern Japan. Journal of Mineralogy, Petrology and Economic Geology, 87, 62-67 (in Japanese with English abstract).

Paquet, M., Cannat, M., Brunelli, D., Hamelin, C. and Humler, E. (2016) Effect of melt/mantle interactions on MORB chemistry at the easternmost Southwest Indian Ridge $\left(61^{\circ}-67^{\circ} \mathrm{E}\right)$. Geochemistry, Geophysics, Geosystems, 17, 4605-4640, doi:10. 1002/2016GC006385.

Research Group of the Tokoro Belt (1984) Petrographic constitution of the Nikoro Group and the significanse of unconformity at the base of the Saroma Group, the Tokoro Belt, Hokkaido. Earth Science (Chikyukagaku), 38, 408-419 (in Japanese with English abstract).

Sakai, S., Hirano, N., Dilek, Y., Machida, S., et al. (2019) Tokoro Belt (NE Hokkaido): an exhumed, Jurassic - Early Cretaceous seamount in the Late Cretaceous accretionary prism of northern Japan. Geological Magazine, doi:10.1017/S0016756819000633.

Sakakibara, M. (1986) A newly discovered high-pressure terrain in eastern Hokkaido, Japan. Journal of Metamorphic Geology, 4 , 401-408.

Sakakibara, M., Niida, K., Toda, H., Kito, N., et al. (1986) Nature and tectonic history of the Tokoro belt. Monograph of the Association for the Geological Collaboration in Japan, 31, 173-187 (in Japanese with English abstract).

Sato, H., Kumagai, H., Neo, N. and Nakamura, K. (2008) variations of chemical compositions of mid-ocean ridge basalts (MORB) and their origin. Journal of Geography, 117, 124145 (in Japanese with English abstract).

Seton, M., Flament, N., Whittaker, J., Müller, R.D., et al. (2015) Ridge subduction sparked reorganization of the Pacific platemantle system 60-50 million years ago. Geophysical Research Letters, 42, 1732-1740.

Shervais, J.W. (1982) Ti-V plots and the petrogenesis of modern and ophiolitic lavas. Earth and Planetary Science Letters, 59, 101-118.

Sun, S.-S. and McDonough, W.F. (1989) Chemical and isotopic systematics of oceanic basalts: implications for mantle composition and processes. In Magmatism in the Ocean Basins (Saunders, A.D. and Norry, M.J., Eds.). Geological Society Special Publication, 42, 313-345.

Thorkelson, D.J. and Breitsprecher, K. (2005) Partial melting of slab window margins: genesis of adakitic and non-adakitic magmas. Lithos, 79, 25-41.

Toda, H. and Niida, K. (1986) Magmatism of greenstones in Tokoro Belt. Tectonic belt of Hokkaido - Petrology and tectonics, 1, 90-97 (in Japanese).

Ueda, H. (2016) Hokkaido. In The Geology of Japan (Moreno, T., Wallis, S., Kojima, T. and Gibbons, W. Eds.). Geological Society, London, 201-221.

Usuki, T., Kaiden, H., Misawa, K. and Shiraishi, K. (2006) Sensitive high-resolution ion microprobe U-Pb ages of the Latest Oligocene-Early Miocene rift-related Hidaka high-temperature metamorphism in Hokkaido, northern Japan. Island Arc, $15,503-516$.

Yamasaki, T. (2014) XRF major element analyses of silicate rocks using 1:10 dilution ratio glass bead and a synthetically extended calibration curve method. Bulletin of the Geological Survey of Japan, 65, 97-103.

Yamasaki, T. and Yamashita, K. (2016) Whole rock multiple trace element analyses using fused glass bead by laser ablationICP-MS. Bulletin of the Geological Survey of Japan, 67, 27-40.

Yamasaki, T. and Nanayama, F. (2018) Immature intra-oceanic arc-type volcanismon the Izanagi Plate revealed by the geochemistry of the Daimaruyama greenstones in the Hiroo Complex, southern Hidaka Belt, central Hokkaido, Japan. Lithos, 302-303, 224-241.

Yamasaki, T., Yamashita, K., Ogasawara, M. and Saito, G. (2015) Multiple trace element analyses for silicate minerals and glasses by laser ablation-inductively coupled plasma-mass spectrometry (LA-ICP-MS). Bulletin of the Geological Survey of Japan, 66, 179-197.

Yamasaki, T., Nanayama, F., Takahashi, Y. and Yamashita, K. (2018) Whole-rock geochemical compositions of igneous-origin rocks from the 1:200,000, Hiroo Quadrangle and related area. Bulletin of the Geological Survey of Japan, 69, 47-79 (in Japanese with English abstract).

Manuscript received June 17, 2019

Manuscript accepted January 31, 2020

Published online February 29, 2020

Manuscript handled by Masaaki Owada 